\title{
Determination of trace elements in gluten-free food for celiac people by ICP-MS
}

\author{
Santino Orecchio ${ }^{\text {a, }}$, Diana Amorello ${ }^{a}$, Maria Raso ${ }^{b}$, Salvatore Barreca ${ }^{a}$, Claudia Lino ${ }^{a}$, Francesca Di Gaudio ${ }^{\text {b }}$ \\ a Dipartimento di Scienze e Tecnologie Biologiche, Chimiche e Farmaceutiche, Università di Palermo, Viale delle Scienze, I-90128 Palermo, Italy \\ b Dipartimento: DiBiMeF (Biopatologia e Biotecnologie Mediche e Forensi) - Sez. Chimica e Biochimica Medica, Azienda Ospedaliera Universitaria Paolo Giaccone, Università di Palermo, \\ Via del Vespro, I-90128 Palermo, Italy
}

\section{A R T I C L E I N F O}

\section{Article history:}

Received 24 March 2014

Received in revised form 17 April 2014

Accepted 22 April 2014

Available online 2 May 2014

\section{Keywords:}

Gluten-free foods

Metals

ICP-MS

Celiac

\begin{abstract}
A B S T R A C T
This paper is the first analytical approach to the study of twenty heavy metals in the gluten-free foods for celiac people. Only the ICP-MS technique was used. One of the advantages about the use of ICP-MS for this characterization is the high sensitivity that improved the limits of quantification levels for some elements that are present at low quantities in some samples.

The concentration values of As, Ba, Cd, Co, Cr, Cu, Fe, $\mathrm{Hg}$, Mn, Mo, Ni, Pb, Sb, Se, Sn, V and Zn in seventeen glutenfree food samples are reported.

The highest arsenic and molybdenum levels were measured in Rice noodle from China $\left(0.088 \mathrm{and} 0.47 \mathrm{mg} \mathrm{kg}{ }^{-1}\right.$, respectively). The highest concentrations of some metals ( $\mathrm{Cu}, \mathrm{Ba}, \mathrm{Cd}, \mathrm{Pb}, \mathrm{Hg}, \mathrm{Sr}$ and $\mathrm{V}$ ) were found in bread and breadstick samples produced in different bakeries located at Palermo.

To examine the overall heavy metal concentrations in all gluten-free samples analyzed, metal pollution index (MPI) was calculated.

Gluten-free foods analyzed contain levels of trace elements under the limits tolerated by the law.

Considering the average concentrations of some trace elements found in the present study, it can be concluded that they are inadequate if compared with the recommended daily intake by international organisms, providing from 1.1 to $53 \%$ of the RDI for the essential metals. These conclusions are in good agreement to some authors affirming that commercial gluten-free cereal foods, made of refined flours or starches, are of lower nutritional value compared to their wheat counterparts.

The metal pollution index and health risk index of heavy metals also suggest that $\mathrm{Cd}, \mathrm{Pb}$ and $\mathrm{Ni}$ contamination in most of the test gluten-free food had potential for human health risk due to consumption of food at contaminated not industrial laboratory. Considering our data, health risk index was lower than 1 for all the samples except nickel in a sample of pasta.
\end{abstract}

(c) 2014 Elsevier B.V. All rights reserved.

\section{Introduction}

Celiac disease is an intolerance for gluten in genetically predisposed individuals and is characterized by an inappropriate immune response of the T-lymphocytes of the small intestines to gluten peptides [1]. Epidemiological researches indicate that celiac disease is common and that the prevalence of celiac disease is approximately $1 \%$ in the general population [2]. Cases of celiac disease are increasing as well as the prevalence in elderly people is becoming evident [3]. The only available treatment is a lifelong strict gluten-free diet, which leads to restoration of the atrophied intestinal villi.

Today, consumption and baking of gluten-free products have become easier, with increases in the number and quality of gluten-free food

\footnotetext{
* Corresponding author.

E-mail address: santino.orecchio@unipa.it (S. Orecchio).
}

products that are available in some food stores. Celiac consumers can purchase premade gluten-free breads, pastas, crusts, desserts and more. Baking mixes and flours are offered to bake breads, pastas, cake and other foods. Ordinary ingredients of gluten-free foods are starch and flour of corn, potato, tapioca, rice, etc. In few cases, flours are fortified with vitamins and minerals, such as B vitamins and iron. Gluten-free foods tend to be high in fat and calories to enhance flavor, texture and appearance [3].

Several authors [4-6] found that many gluten-free cereal products, compared with the enriched wheat products contain lower amounts of thiamin, riboflavin, niacin, folate and iron products that they are intended to replace.

Three-day estimated self-reported gluten-free food records were used to assess daily intakes of calories, percent daily calories from carbohydrates, dietary fibers, iron, calcium and grain food servings, by using forty-seven celiac volunteers. The results suggested inadequate intakes of fiber, iron, and calcium in 50\% of celiac females studied [6]. Today, no data exist on the other essential elements. 
Often, patients that carry out a gluten-free diet need assistance from a dietician. In these cases, unfortunately, dieticians have no knowledge regarding essential and microelements composition; it is for this reason that it is necessary to know the composition of the foods used by individuals with celiac disease and, nowadays, data do not exist.

Trace elements have an important role in human biology, because they are not synthesized in the body. Trace amounts of some metals, manganese, copper, and zinc, for example, are essential micro nutrients and have a variety of biochemical functions in all living organisms. While these elements are essential, they can be toxic when taken in excess. Also, some metals like lead, do not occur naturally in the body, and their presence, usually as a result of environmental or pollution-related exposure, are harmful to human health and children; elderly and patients are more sensitive to these metals than adults.

Some minerals may constitute a potential health risk if consumed above the tolerable upper in-take levels over an extended period. Examples of these are iodine, lead, arsenic, cadmium and mercury poisoning. For other minerals, the negative effects are less obvious, e.g. gastrointestinal problems. For non-essential elements exposures are undesirable, but acceptable levels in food have been determined by the World Health Organization (WHO) and other international authorities [7-9].

The majority of mineral components that must be determined in diet samples are present at trace and ultra-trace levels; hence analytical techniques $[10,11]$ with adequate sensitivity are required for their accurate determinations. Additionally, it is important to remember that the accuracy of the quantitative analytic procedure is strongly dependent on the sampling and sample preparation steps. The techniques most employed for trace element analysis in foods are those based on atomic spectrometry and inorganic mass spectrometry.

In Italy, about 4 in 1000 people have celiac disease and among people who have a first-degree relative diagnosed with celiac disease, as many as 1 in 22 people may have the disease. In general, celiac disease could be under diagnosed because celiac symptoms can be attributed to other problems and only a little number of laboratories are experienced and skilled in testing for the disease.

The aim of this study was to obtain data on the mineral and trace elements content of selected gluten-free foods for celiac people, in particular, Italian products (pasta, breads, flours, etc.). Considering the high number of celiac, these information are urgently required so that the daily dietary element intakes in the celiac population can be estimated from available food consumption data. While element intake levels for non-celiac people are documented [12-15] there is as yet no information available for celiac ones. Also, this study wants to investigate if any toxic elements could be found in the gluten-free foods and the daily intake from diets composed according to reference intake levels. The study included 27 different products for celiac people from several manufacturers.

The concentrations of seventeen minerals and trace elements were determined by Inductively Coupled Plasma Mass Spectrometry (ICP-MS).

\section{Experimental part}

\subsection{Quality control and quality assurance}

All the vessels and flasks were cleaned before use by rinsing three times with $\mathrm{HNO}_{3}(1 \%)$ and three times with Milli-Q water. All the analyses of metals in gluten-free food samples were repeated three times and the relative standard deviation results ranged from 1 to $5 \%$. Periodically, blanks were run up and demonstrate that the treatment used for cleaning vessels and flasks is suitable to obtain the quality assurance required in this study.

The repeatability, calculated as the relative standard deviation (RSD\%) of three independent measurements of a multi-elemental standard solution at $10 \mathrm{ng} \cdot \mathrm{mL}^{-1}$, ranged from 0.3 to $8.0 \%$. The repeatability of the whole method, calculated as the relative standard deviation (RSD\%), for three independent analysis of independent portions of the same sample, ranged from 0.2 to $8.8 \%$. A blank was run up every five samples. All reported data were blank corrected.

\subsection{Samples}

Twenty-seven samples of gluten-free products (pasta, biscuits, flours, etc), produced in Italy were collected in 2013 from markets and pharmacies in Palermo city (Italy). Only the bread and breadsticks were produced in local (Palermo and neighborhood) bakeries. The samples selected were representative of the Italian market. Samples were milled and homogenized by using a food processor (plastic-coated) and then sub-sampled for analysis. Samples were handled immediately or stored in the refrigerator at $4{ }^{\circ} \mathrm{C}$ until analysis for a period of less than $24 \mathrm{~h}$. From each gluten-free food sample, three aliquots were digested and each sample solution was analyzed in triplicates.

\subsection{Sample digestion}

A microwave oven (Milestone model MLS-1200 Mega, Milestone Laboratory Systems, Italy) with rotor of high pressure (up to 100 bar) was used for sample digestions. About $0.2 \mathrm{~g}$ of previously homogenized samples were weighted, transferred inside Teflon vessels and $2 \mathrm{~mL}$ of $\mathrm{HNO}_{3}$ (69\%) (Fluka, Milano) and $1 \mathrm{~mL}$ of $\mathrm{H}_{2} \mathrm{O}_{2}$ (30\%) (Fluka, Milano) were added. The instrumental conditions used for the microwave digestion were: $1 \mathrm{~min}$ at $250 \mathrm{~W}, 1 \mathrm{~min}$ at $0 \mathrm{~W}, 5 \mathrm{~min}$ at $250 \mathrm{~W}, 5 \mathrm{~min}$ at $450 \mathrm{~W}, 3 \mathrm{~min}$ at $600 \mathrm{~W}$ and $5 \mathrm{~min}$ at $300 \mathrm{~W}$. After digestion, the clear, colorless solution was transferred into a volumetric flask and brought to volume with Milli- $\mathrm{Q}$ water $\left(\mathrm{R}>20 \mathrm{M} \Omega \mathrm{cm}^{-1}\right.$ ) (Merck Millipore).

\subsection{ICP-MS analysis}

Elemental analyses were carried out by using Thermo ICP-MS instrument (X Series II) equipped with a collision cell. Each solution was measured three times and ICP-MS analyses were carried out with a classical external calibration approach. It was carried out from 0.1 to $1000 \mathrm{ng} \cdot \mathrm{mL}^{-1}$ for each investigated element using ${ }^{89} \mathrm{Y}$ and ${ }^{187} \mathrm{Re}$ ( $50 \mathrm{ng} \cdot \mathrm{mL}^{-1}$ ) as internal standards to compensate for any signal instability and all data in cps were normalized to the internal standard; a solution of $\mathrm{HNO}_{3} 2 \%$ as blank was used. The instrumental parameters are shown in Table 1 . The analysis of standard solutions was replicated in every eight samples. Correlation coefficients of the calibration curves were in the range from 0.9985 to 1.0000 . To eliminate memory effects, a washing cycle of $30 \mathrm{~s}$ was settled between two subsequent samples. A blank was run up every five samples and all reported data were blank corrected.

The analytical results of the ICP-MS instrument strongly depends on the operating conditions [16,17]. A solution containing Li, Be, Mg, Co, In, $\mathrm{Ba}, \mathrm{Ce}, \mathrm{Pb}, \mathrm{Bi}$, and $\mathrm{U}$ was used to optimize the instrument in terms of sensitivity, resolution and mass calibration. The ${ }^{140} \mathrm{Ce}^{16} \mathrm{O}^{+}:{ }^{140} \mathrm{Ce}^{+}$ ratio was used to check the level of oxide ions in the plasma that could interfere in the determination of some elements; also, instrumental parameters such as RF power and carrier gas flow were optimized and the level of doubly charged ion was monitored by means of the signal $\mathrm{Ba}^{2+} / \mathrm{Ba}^{+}$.

The analysis of some elements by ICP-MS is well-known to suffer from polyatomic isobaric interferences. For example, regarding some metals of our interest, the vanadium signal at $\mathrm{m} / \mathrm{z} 51$ is affected by ${ }^{35} \mathrm{Cl}^{16} \mathrm{O}^{+}$, the chromium signal at $\mathrm{m} / \mathrm{z} 53$ is affected by ${ }^{40} \mathrm{Ar}^{13} \mathrm{C}^{+}$and ${ }^{37} \mathrm{Cl}^{16} \mathrm{O}^{+}$, the nickel signal at $\mathrm{m} / \mathrm{z} 58$ is affected by ${ }^{42} \mathrm{Ca}^{16} \mathrm{O}^{+}$, the arsenic signal at $\mathrm{m} / \mathrm{z} 75$ is affected by ${ }^{40} \mathrm{Ar}^{35} \mathrm{Cl}^{+}$and, finally, the selenium signal at $\mathrm{m} / \mathrm{z} 80$ is affected by ${ }^{40} \mathrm{Ar}^{40} \mathrm{Ar}^{+}$. The collision cell (CCT) is proved to be an effective method for relieving such isobaric interferences. The optimization of the $\mathrm{He}_{2}$ flow rate was carried out using matrix blank solution prepared with $\mathrm{HCl}(2 \%), \mathrm{HNO}_{3}(1 \%)$ and a matrix blank solution spiked with $\mathrm{V}$, As and Se at $10 \mathrm{ng} \cdot \mathrm{mL}^{-1}$. 
Table 1

Parameters and operating conditions for the ICP-MS instrument.

\begin{tabular}{|c|c|}
\hline rf power $(\mathrm{W})$ & 1400 \\
\hline Nebulizer (carrier gas) flow rate (l/min) & 0.95 \\
\hline Resolution (amu) & 0.70 \\
\hline Detector & Dual \\
\hline Speed of peristaltic pump (rpm) & 30 \\
\hline Replicates & 3 \\
\hline Dwell time & $30 \mathrm{~ms}$ \\
\hline Scan mode & Peak hopping \\
\hline \multicolumn{2}{|l|}{ Collision cell parameters } \\
\hline $\mathrm{He}_{2} / \mathrm{H}_{2}$ reaction gas flow & $4.0 / 0.5 \mathrm{~mL} / \mathrm{min}$ \\
\hline Isotopes monitored in standard mode & ${ }^{55} \mathrm{Mn},{ }^{56} \mathrm{Fe},{ }^{59} \mathrm{Co},{ }^{137} \mathrm{Ba},{ }^{138} \mathrm{Ba},{ }^{80} \mathrm{Se},{ }^{88} \mathrm{Sr},{ }^{118} \mathrm{Sn},{ }^{200} \mathrm{Hg},{ }^{202} \mathrm{Hg},{ }^{208} \mathrm{~Pb}$ \\
\hline Isotopes monitored in DRC mode & ${ }^{59} \mathrm{Co},{ }^{75} \mathrm{As},{ }^{52} \mathrm{Cr},{ }^{111} \mathrm{Cd},{ }^{51} \mathrm{~V},{ }^{57} \mathrm{Fe}{ }^{60} \mathrm{Ni},{ }^{78} \mathrm{Se},{ }^{63} \mathrm{Cu},{ }^{65} \mathrm{Cu},{ }^{66} \mathrm{Zn},{ }^{68} \mathrm{Zn},{ }^{95} \mathrm{Mo},{ }^{121} \mathrm{Sb}$ \\
\hline
\end{tabular}

Seventeen elements (As, Ba, Cd, Co, Cr, Cu, Fe, Hg, Mn, Mo, Ni, Pb, Sb $\mathrm{Se}, \mathrm{Sn}, \mathrm{V}$ and $\mathrm{Zn}$ ) were determined in each sample, chosen on the basis of their significance in the study of gluten-free food. The data reported in this paper have been calculated considering the average of the values obtained at the different masses that, for all analytes, differed by less than $5 \%$. A total of 27 samples were analyzed by about three determinations of single elements.

The detection limit (LOD) and the quantification limit (LOQ) were estimated as reported in previous papers $[10,18]$. LOD and LOQ values are reported in Table 2 .

\section{Results}

Table 2 shows the concentration values of $\mathrm{As}, \mathrm{Ba}, \mathrm{Cd}, \mathrm{Co}, \mathrm{Cr}, \mathrm{Cu}, \mathrm{Fe}$, $\mathrm{Hg}, \mathrm{Mn}, \mathrm{Mo}, \mathrm{Ni}, \mathrm{Pb}, \mathrm{Sb}, \mathrm{Se}, \mathrm{Sn}, \mathrm{V}$ and $\mathrm{Zn}$ in the different gluten-free food analyzed, expressed in $\mathrm{mg} \mathrm{kg}^{-1}$ of dry sample. Results are expressed as the average of three analyses.

The range of antimony values found in gluten free food samples was $0.0011-0.028 \mathrm{mg} \mathrm{kg}^{-1}$. The mean value was $0.011 \mathrm{mg} \mathrm{kg}^{-1}$. The highest values were detected in the samples no. 23 (biscuit) $\left(0.028 \mathrm{mg} \mathrm{kg}^{-1}\right)$, no. 6 (pasta) $\left(0.027 \mathrm{mg} \mathrm{kg}^{-1}\right)$, no. 14 (flour for cakes) $\left(0.026 \mathrm{mg} \mathrm{kg}^{-1}\right)$ and no. 15 (lasagna) $\left(0.024 \mathrm{mg} \mathrm{kg}^{-1}\right)$. Results found through this study were of the same level than those reported in the literature for cereals $[19,20]$.

The arsenic content of the gluten free food samples ranged from $4 \cdot 10^{-4}$ to $0.088 \mathrm{mg} \mathrm{kg}^{-1}$ with an average of $0.023 \mathrm{mg} \mathrm{kg}^{-1}$. The highest arsenic level was measured in Rice noodle from China which contained $0.088 \mathrm{mg} \mathrm{kg}^{-1}$. The As levels quantified in analyzed foodstuffs were lower than maximum corresponding levels set by EC (1881/2006) [7]. The likely source of arsenic can be the water with which the paddies are flooded. In particular, in several countries arsenic compounds are used as herbicides and fungicides and are possible hypothesize migration processes from water to plant. A limit for arsenic in rice products has not been established. However the World Health $0 \mathrm{mg} \mathrm{kg}{ }^{-1}$ organization (WHO) has established a Provisional Tolerable Weekly Intake (PTWI) of $0.015 \mathrm{mg} \mathrm{kg}^{-1}$ b.w. for inorganic arsenic [8].

In the present study, barium was detected in all analyzed food and the concentration ranged from 0.04 to $2.8 \mathrm{mg} \mathrm{kg}^{-1}$. The highest content was found by us in the sample no. 19 (local bread). In cereals and cereal products, high barium concentration was found by Millour [22] in two samples of muesli with contents respectively of 3.35 and $12.7 \mathrm{mg} \mathrm{kg}^{-1}$. The mean Ba concentration $\left(0.55 \mathrm{mg} \mathrm{kg}^{-1}\right)$ found in the present paper is of the same order as those reported for cereals and cereal products [22].

The cadmium content of the analyzed samples ranges from 0.002 to $0.12 \mathrm{mg} \mathrm{kg}^{-1}$. The mean value was $0.017 \mathrm{mg} \mathrm{kg}^{-1}$ and the highest $\mathrm{Cd}$ concentration in food for celiac consumers was found in a shortbread sample (no. 22) (0.12 $\mathrm{mg} \mathrm{kg}^{-1}$ ) followed by a corn flakes sample (no. 16) $\left(0.040 \mathrm{mg} \mathrm{kg}^{-1}\right)$. The limits for cadmium in wheat and rice established by Codex Alimentarius are respectively 0.2 and $0.4 \mathrm{mg} \mathrm{kg}^{-1}$
[8], moreover, the WHO has also suggested a PTWI of $0.007 \mathrm{mg} \mathrm{kg}^{-1}$ b.w. All analyzed celiac food samples were well below the prescribed limits. Some authors $[7,8]$ reported Cd concentrations between 0.012 and $0.216 \mathrm{mg} \mathrm{kg}^{-1}$ in vegetables.

The cobalt concentration ranged from $3 \cdot 10^{-4}$ to $0.54 \mathrm{mg} \mathrm{kg}^{-1}$ with an average value of $0.084 \mathrm{mg} \mathrm{kg}^{-1}$. Cobalt is an essential trace element, particularly is a component of some metalloproteins and vitamin B12 also called "cobalamin", a water-soluble vitamin with a key role in the normal functioning of the brain and nervous system, and for the formation of blood.

The chromium concentration in analyzed foods ranged from 0.0091 to $14.4 \mathrm{mg} \mathrm{kg}^{-1}$. The highest $\mathrm{Cr}$ level was found in sample no. 15 (lasagna). The mean $\mathrm{Cr}$ concentration was $3.9 \mathrm{mg} \mathrm{kg}^{-1}$. Humans require chromium in trace amounts. Its mechanisms in the body are not well defined but it is known to enhance the action of insulin, and appears to aid in the metabolism and storage of protein, carbohydrates and fats. Chromium is present in very low levels in food and absorption rates in the body are low, between $0.4 \%$ and $2.5 \%$. Adequate intake recommendations vary by age and gender, the Recommended Daily Intake for most adult females is $25 \mathrm{mg} \mathrm{day}^{-1}$ and $35 \mathrm{mg} \mathrm{day}^{-1}$ for most adult males (NIH).

Copper is essential to humans in small quantities as a component of redox enzymes and hemocyanin; it is involved in mitochondrial function, cellular metabolism, connective tissue formation, and the absorption, storage and metabolism of iron. The copper concentration of celiac food samples ranged from 0.14 to $1.8 \mathrm{mg} \mathrm{kg}^{-1}$ with an average concentration value of $0.99 \mathrm{mg} \mathrm{kg}^{-1}$. The highest $\mathrm{Cu}$ concentrations were found in two bread samples (no. 19 and no. 20) produced in different local bakeries. The maximum copper levels in bread samples, found by Demirozu [21], were $9.6 \mathrm{mg} \mathrm{kg}^{-1}$. It is difficult to assess health risk of copper for celiac consumers from rice and vegetables since there is no standard maximum limit for this element in food. The WHO has also suggested a dietary reference adequate intake (AI) of $0.900 \mathrm{mg} \mathrm{day}^{-1}$ and a tolerable upper intake for males and females (aged 19-70 years) of $10 \mathrm{mg}$ day $^{-1}$.

The lead concentration in analyzed gluten free food ranged from 0.0013 to $1.1 \mathrm{mg} \mathrm{kg}^{-1}$. The highest Pb level was found in sample no. 22 (shortbread), while the mean $\mathrm{Pb}$ concentration was $0.13 \mathrm{mg} \mathrm{kg}^{-1}$. The $\mathrm{Pb}$ levels in six of twenty-seven investigated foodstuffs were found to be higher than maximum levels $\left(0.2 \mathrm{mg} \mathrm{kg}^{-1}\right.$ for cereals, legumes and pulses) set by EC (1881/2006).

Food contamination during laboratory productions or their raw material contaminations could be the main reasons for the high concentrations of this element. In fact, the heterogeneity of Pb concentrations in bread samples analyzed by some authors range between 0.023 and $1.8 \mathrm{mg} \mathrm{kg}^{-1}$ in samples obtained from the different bakeries.

Lead creates health disorders such as sleeplessness, tiredness, hear and weight loss. The International Agency for Research on Cancer classified inorganic lead as probably carcinogenic to humans (Group 2) in 2006 (IARC, 2006) [22]. 
Table 2

Metals concentrations ( $\mathrm{mg} \cdot \mathrm{Kg}^{-1} \mathrm{~d} . w$. ) in gluten-free food samples analyzed.

\begin{tabular}{|c|c|c|c|c|c|c|c|c|c|c|c|c|c|c|c|c|c|c|}
\hline Sample & $\mathrm{V}$ & $\mathrm{Cr}$ & $\mathrm{Mn}$ & Co & $\mathrm{Ni}$ & $\mathrm{Cu}$ & $\mathrm{Zn}$ & As & Se & $\mathrm{Sr}$ & Mo & $\mathrm{Cd}$ & Sn & $\mathrm{Sb}$ & $\mathrm{Ba}$ & $\mathrm{Hg}$ & $\mathrm{Pb}$ & $\mathrm{Fe}$ \\
\hline 1 Pasta & 0.0001 & 0.0091 & 0.47 & 0.0003 & 0.016 & 0.3 & 1.2 & 0.0004 & 0.010 & 0.016 & 0.074 & 0.0019 & 0.0071 & 0.0018 & 0.04 & 0.0010 & 0.33 & 1.1 \\
\hline 2 Noodles & 0.0008 & 0.0268 & 1.6 & 0.0026 & 0.049 & 0.6 & 4.4 & 0.013 & 0.026 & 0.36 & 0.134 & 0.0043 & 0.0085 & 0.0044 & 0.38 & 0.0008 & 0.0061 & 4.6 \\
\hline 3 Flour & 0.0045 & 0.015 & 1.3 & 0.0016 & 0.022 & 0.1 & 1.1 & 0.0083 & 0.0076 & 0.38 & 0.041 & 0.0030 & 0.0008 & 0.0029 & 0.41 & 0.0005 & 0.0013 & 2.6 \\
\hline 4 Biscuits & 0.0044 & 0.015 & 3.9 & 0.0086 & 0.22 & 0.94 & 4.6 & 0.0064 & 0.016 & 0.18 & 0.108 & 0.010 & 0.0039 & 0.0045 & 0.17 & 0.0004 & 0.0051 & 4.6 \\
\hline 5 Pasta fusilli & 0.0039 & 0.011 & 1.4 & 0.0008 & 0.25 & 0.49 & 3.8 & 0.0004 & 0.017 & 0.11 & 0.033 & 0.0019 & 0.0026 & 0.0025 & 0.09 & 0.0001 & 0.0033 & 6.2 \\
\hline 6 Pasta linguine & 0.0075 & 0.078 & 1.4 & 0.0570 & 0.53 & 0.49 & 3.8 & 0.0004 & 0.014 & 0.11 & 0.035 & 0.0018 & 0.0009 & 0.027 & 0.08 & 0.0001 & 0.0035 & 9.5 \\
\hline 7 Egg noodles & 0.0021 & 0.031 & 1.9 & 0.0025 & 0.06 & 0.46 & 4.0 & 0.011 & 0.058 & 0.77 & 0.093 & 0.0084 & 0.0034 & 0.0026 & 0.26 & 0.0001 & 0.0014 & 5.4 \\
\hline 8 Finger biscuits & 0.0065 & 0.16 & 0.80 & 0.0028 & 0.10 & 0.4 & 5.6 & 0.017 & 0.065 & 1.13 & 0.20 & 0.0024 & 0.0026 & 0.0096 & 0.31 & 0.0024 & 0.04 & 8.9 \\
\hline 9 Buckwheat biscuits & 0.0093 & 0.040 & 5.0 & 0.0178 & 0.33 & 1.6 & 6.5 & 0.019 & 0.015 & 0.23 & 0.26 & 0.0174 & 0.0026 & 0.0093 & 0.45 & 0.0030 & 0.03 & 8.3 \\
\hline 10 Croutons & 0.028 & 0.21 & 7.5 & 0.0270 & 0.50 & 0.63 & 3.6 & 0.022 & 0.037 & 4.7 & 0.37 & 0.0079 & 0.0028 & 0.019 & 0.76 & 0.0031 & 0.04 & 13.7 \\
\hline 11 Rice noodles & 0.0033 & 0.13 & 5.1 & 0.0151 & 0.14 & 1.7 & 10.7 & 0.088 & 0.027 & 0.44 & 0.47 & 0.026 & 0.0028 & 0.0083 & 1.00 & 0.0049 & 0.03 & 3.6 \\
\hline 12 Couscous & 0.0029 & 0.040 & 1.0 & 0.0101 & 0.31 & 0.48 & 3.2 & 0.0081 & 0.023 & 0.16 & 0.20 & 0.0044 & 0.0026 & 0.0053 & 0.15 & 0.0015 & 0.02 & 4.3 \\
\hline 13 Corn couscous & 0.0054 & 0.063 & 0.81 & 0.024 & 0.12 & 0.37 & 2.9 & 0.0078 & 0.0088 & 0.16 & 0.11 & 0.0028 & 0.0026 & 0.010 & 0.14 & 0.0010 & 0.02 & 5.0 \\
\hline 14 Flour for cakes & 0.0085 & 0.078 & 0.39 & 0.0048 & 0.04 & 0.33 & 6.7 & 0.011 & 0.072 & 1.4 & 0.18 & 0.0026 & 0.0026 & 0.024 & 0.53 & 0.0010 & 0.03 & 9.8 \\
\hline 15 Lasagna & 0.071 & 14.4 & 2.5 & 0.54 & 15.0 & 1.5 & 7.2 & 0.017 & 0.062 & 1.8 & 0.41 & 0.021 & 0.0030 & 0.026 & 0.88 & 0.0325 & 0.21 & 99 \\
\hline 16 Corn flakes & 0.028 & 8.4 & 2.1 & 0.15 & 10.3 & 1.1 & 3.3 & 0.0086 & 0.062 & 0.70 & 0.30 & 0.040 & 0.0084 & 0.0066 & 0.91 & 0.0183 & 0.34 & 55 \\
\hline 17 Dietetic biscuits & 0.049 & 9.1 & 1.5 & 0.15 & 10.0 & 1.2 & 3.7 & 0.014 & 0.016 & 1.4 & 0.24 & 0.013 & 0.0031 & 0.014 & 0.61 & 0.065 & 0.19 & 62 \\
\hline 18 Breadsticks & 0.035 & 8.7 & 4.4 & 0.16 & 10.5 & 1.1 & 5.0 & 0.036 & 0.026 & 0.75 & 0.28 & 0.020 & 0.0030 & 0.013 & 0.44 & 0.082 & 0.10 & 62 \\
\hline 19 Local bread B. & 0.074 & 8.7 & 3.1 & 0.17 & 10.3 & 1.7 & 5.8 & 0.014 & 0.019 & 5.1 & 0.24 & 0.023 & 0.0031 & 0.017 & 2.8 & 0.037 & 0.26 & 66 \\
\hline 20 Local bread P. & 0.036 & 8.7 & 4.8 & 0.16 & 10.2 & 1.8 & 8.4 & 0.056 & 0.013 & 2.2 & 0.33 & 0.032 & 0.0046 & 0.016 & 0.63 & 0.13 & 0.39 & 70 \\
\hline 21 Corn flakes & 0.031 & 8.1 & 2.1 & 0.15 & 10.0 & 1.1 & 3.5 & 0.0086 & 0.065 & 0.56 & 0.29 & 0.024 & 0.0035 & 0.0049 & 0.88 & 0.013 & 0.20 & 60 \\
\hline 22 Shortbread & 0.033 & 9.7 & 3.8 & 0.19 & 12.4 & 1.4 & 137 & 0.044 & 0.033 & 0.51 & 0.36 & 0.12 & 0.0031 & 0.0096 & 0.62 & 0.015 & 1.09 & 80 \\
\hline 23 Biscuits & 0.057 & 14.0 & 4.7 & 0.20 & 14.0 & 1.6 & 7.4 & 0.032 & 0.051 & 0.94 & 0.35 & 0.016 & 0.0028 & 0.028 & 0.46 & 0.022 & 0.074 & 83 \\
\hline 24 Butter cookies & 0.054 & 14.0 & 4.6 & 0.19 & 13.8 & 1.1 & 6.0 & 0.043 & 0.009 & 0.32 & 0.42 & 0.024 & 0.0028 & 0.016 & 0.58 & 0.021 & 0.063 & 75 \\
\hline 25 Croutons & 0.005 & 0.031 & 4.4 & 0.013 & 0.11 & 1.8 & 6.7 & 0.062 & 0.021 & 1.5 & 0.36 & 0.014 & 0.0026 & 0.0011 & 0.38 & 0.017 & 0.026 & 10 \\
\hline 26 Egg biscuits & 0.014 & 0.035 & 6.1 & 0.011 & 0.21 & 1.3 & 6.3 & 0.055 & 0.016 & 1.6 & 0.32 & 0.021 & 0.0026 & 0.0013 & 0.32 & 0.0095 & 0.028 & 4.6 \\
\hline 27 Industrial bread & 0.052 & 0.054 & 2.2 & 0.015 & 0.17 & 0.94 & 3.7 & 0.020 & 0.014 & 1.5 & 0.28 & 0.0050 & 0.0026 & 0.0031 & 0.60 & 0.0059 & 0.052 & 21 \\
\hline Mean value & 0.023 & 3.9 & 2.9 & 0.084 & 4.4 & 0.99 & 9.9 & 0.023 & 0.030 & 1.1 & 0.24 & 0.017 & 0.003 & 0.011 & 0.55 & 0.018 & 0.13 & 31 \\
\hline Detection limits & 0.00004 & 0.002 & 0.002 & 0.00007 & 0.003 & 0.002 & 0.002 & 0.0002 & 0.002 & 0.0002 & 0.0002 & 0.0003 & 0.0003 & 0.0004 & 0.0004 & 0.00004 & 0.0004 & 0.0002 \\
\hline Quantification limits & 0.0001 & 0.006 & 0.006 & 0.0002 & 0.006 & 0.005 & 0.005 & 0.0004 & 0.007 & 0.0004 & 0.0004 & 0.0008 & 0.0007 & 0.0009 & 0.001 & 0.0001 & 0.001 & 0.005 \\
\hline
\end{tabular}


Of the 27 food samples analyzed, the highest level of manganese was found in sample no. 10 (croutons) $\left(7.5 \mathrm{mg} \mathrm{kg}^{-1}\right)$, followed by no. 26 (eggs biscuits) $\left(6.1 \mathrm{mg} \mathrm{kg}^{-1}\right.$ ) and no. 11 (rise noodles) $\left(5.1 \mathrm{mg} \mathrm{kg}^{-1}\right.$ ). For the remaining samples, concentrations ranged from $0.39 \mathrm{mg} \mathrm{kg}^{-1}$ (sample no. 14 flour for cakes) to $4.7 \mathrm{mg} \mathrm{kg}^{-1}$ (sample no. 23 biscuit). The mean Mn concentration $(2.9 \mathrm{mg} / \mathrm{kg}$ ) results of the same order as those reported for cereals and cereal products by Noel [23]. Mean Mn concentrations in Indian, Italian, Pakistani, Thai and Vietnamese rice are in the range from 5.4 to $8.0 \mathrm{mg} \mathrm{kg}^{-1}$.

As shown in the Table 2, the levels of iron ranged from 1.1 to $83 \mathrm{mg} \mathrm{kg}^{-1}$. The highest level was detected in sample no. 23 (biscuits), while the lowest one was in sample no. 1 (pasta).

The mercury concentration in the samples varies between $1 \times 10^{-4}$ and $0.082 \mathrm{mg} \mathrm{kg}^{-1}$. The highest $\mathrm{Hg}$ level was found in sample no. 18 (breadsticks).

The molybdenum concentration in analyzed foods ranged from 0.033 to $0.47 \mathrm{mg} \mathrm{kg}^{-1}$. The highest Mo level was found in sample no. 11 (rise noodles). The mean Mo concentration was $0.24 \mathrm{mg} \mathrm{kg}^{-1}$. The Mo results are of the same order as those reported for other food [23, 24].

In the present study, the concentration of nickel ranged from 0.016 to $15 \mathrm{mg} \mathrm{kg}^{-1}$. The highest concentration was found in the lasagna sample (no. 15). The concentrations obtained in this study are much higher than those found in the Bangladeshi, Indian and Pakistani food (rice) [25].

Selenium was detected in all analyzed food for celiac consumers and was in the range $0.0076-0.072 \mathrm{mg} \mathrm{kg}^{-1}$. The highest Se concentrations were found in the samples: no. 14 (flour for cakes) followed by no. 21 (corn flakes) ( $0.065 \mathrm{mg} \mathrm{kg}^{-1}$ ) and no. 8 (finger biscuits) $\left(0.065 \mathrm{mg} \mathrm{kg}^{-1}\right)$. For most of the remaining samples, concentrations were lower than $0.03 \mathrm{mg} \mathrm{kg}^{-1}$. The concentrations found in the present work are compared with those reported in the literature for different foods [26], in particular, the analyzed retail wheat flours showed a low variation in the selenium concentration in the range from 0.022 to $0.042 \mathrm{mg} \mathrm{kg}^{-1}$ despite that the samples were collected from several trademarks without specification of agricultural land of origin.

For Selenium the concentration range $\left(0.01-0.13 \mathrm{mg} \mathrm{kg}^{-1}\right)$ in pasta for celiac people analyzed by us was lower comparable to those reported in other works $\left(0.047-0.064 \mathrm{mg} \mathrm{kg}^{-1}\right)$ for non-celiac [26]. Generally, gluten-free flours have lower Se due to its lower protein content [27]. Selenium deficiency has been suggested to have a role in the etiology of several pathologies, such as oxidative stress or inflammatory conditions, diabetes mellitus, hepatopathies and infections. Diminishing selenium status in some European countries, is giving cause for concern. In fact, about 20 years ago, dietary Se intakes in the UK were $60 \mathrm{mg} \mathrm{day}^{-1}$ on average, whereas a 1994 study found that Se intake is reduced to $34 \mathrm{mg} \mathrm{day}^{-1}$ [27-29], significantly lower than the reference nutrient intakes of $75 \mathrm{mg}$ day $^{-1}$ for men and $60 \mathrm{mg} \mathrm{day}^{-1}$ for women.

The highest strontium content $\left(5.1 \mathrm{mg} \mathrm{kg}^{-1}\right)$ was founded in sample no. 19 (local bread) and the lowest $\left(0.016 \mathrm{mg} \mathrm{kg}^{-1}\right)$ was in the sample no. 1 (pasta).

The range of vanadium concentrations in analyzed gluten-free food was $1 \cdot 10^{-4}-0.074 \mathrm{mg} \mathrm{kg}^{-1}$. Vanadium was detected in almost all the samples analyzed with a mean value of $0.023 \mathrm{mg} \mathrm{kg}^{-1}$. The highest overall value of $0.074 \mathrm{mg} \mathrm{kg}^{-1}$ was founded in the local bread sample (no. 19).

The zinc concentration in analyzed foods ranged from 1.1 to $137 \mathrm{mg} \mathrm{kg}^{-1}$. The highest $\mathrm{Zn}$ level was founded in a shortbread sample no. 22. The $\mathrm{Zn}$ average concentrations obtained through this study are similar to those found in the literature [30]. Zinc is an essential metal in human diet; it is present in several enzymes indispensable for human metabolism. For this element, the RDI value was $11 \mathrm{mg}$ day $^{-1}$.

Good linear correlations are verified between iron and chromium concentrations $\left(\mathrm{R}^{2}=0.9384\right)$ and between iron and nickel

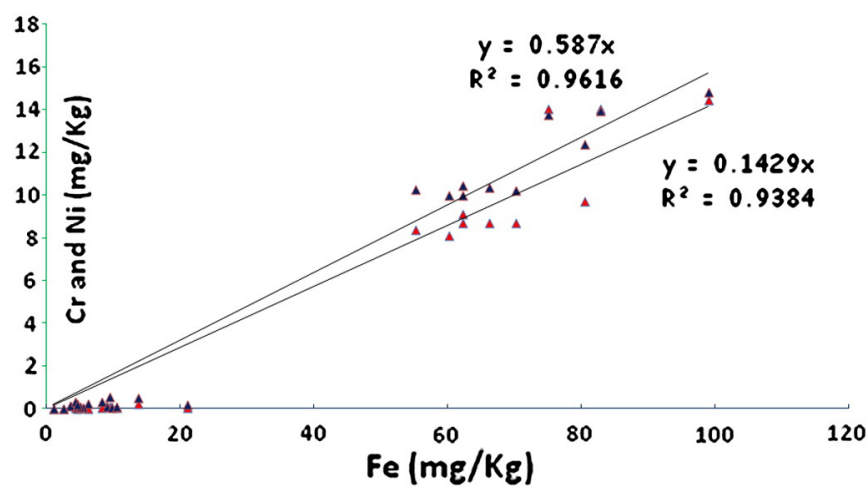

Fig. 1. Correlation between iron and chromium (red triangles) and nickel (blue triangles) in the gluten free food samples. (For interpretation of the references to color in this figure, the reader is referred to the web version of this article.)

concentrations $\left(\mathrm{R}^{2}=0.9616\right)$ (Fig. 1). We assume that the high correlations are useful to prove the same origin of three metals. Iron, chromium and nickel are stainless steel components and therefore may have been released from the machineries used in the food productions.

\subsection{Metal pollution index (MPI)}

To examine the overall heavy metal concentrations in all gluten-free samples analyzed, metal pollution index (MPI) was calculated. This index was obtained by calculating the geometrical mean of concentrations of all the metals in the samples [31].

MPI $=\left(C_{1} \cdot C_{2} \cdot C_{3} \cdot \ldots \cdot C_{n}\right)^{1 / n}$

where $C_{n}=$ concentration of single metal in the sample.

Among different gluten-free food analyzed, shortbread (no. 22) showed the highest value of MPI (0.44) followed by lasagna (no. 15) (0.42) and the local bread samples (nos. 19 and 20) (0.38 and 0.42) respectively. As compared to the previous products, industrial pasta showed lower metal pollution index (Fig. 2).

\subsection{Enrichment factor}

The enrichment factor (EF) [32,33] can be used to discriminate the metals originating from human activities and those from natural sources and to assess the degree of anthropogenic influence. Element enrichment factor, evaluated relative to the background values, was used to establish which elements were relatively enriched in the different gluten-free food samples. Values of EF close to 1 pointed to a natural origin while those greater than 10 are considered to have a non-crustal source [33]. Further, EFs can also assist the determination of the degree of metal contamination. Five contamination categories are recognized on the basis of the enrichment factor (Table 3).

In our case (Table 4 ), the enrichment factors ranged from $9.2 \cdot 10^{-7}$ to 1.8 , in particular, the sample no. 22 (shortbread) showed the highest value of $\mathrm{EF}(1.8)$ for the zinc, followed $(1.6,1.02)$ by samples no. 20 and no. 18 for mercury in the local bread and shortbread and for selenium in four samples (nos. 14, 15, 16 and 24). However these values reflect minimal contamination of considered samples.

\subsection{Daily intake of metals (DIM)}

Given that in literature no data are reported about the estimated metal daily intake for celiac population, it is very important and of great interest to obtain data about daily intake of metals for celiac population as reported in this study. The daily intake depends both on the level of metals in the food and the amount consumed. The main food 


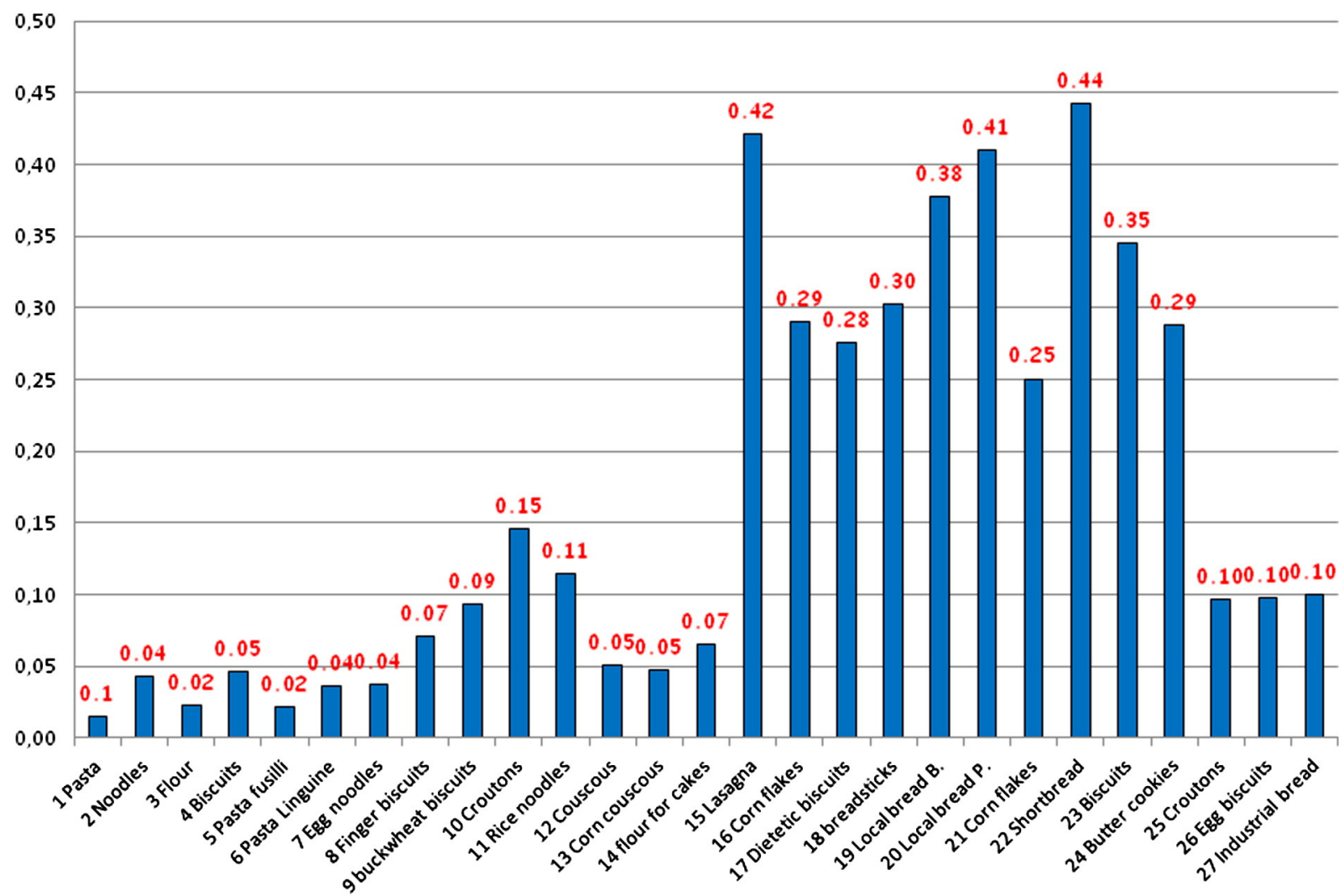

Fig. 2. Metal pollution index for gluten-free food samples.

of Italian celiac consumers is pasta and food prepared using flours, hence metal levels in cereals contribute a major part to the total daily intake. Daily intake of metals was calculated using the following equation:

$\mathrm{DIM}=\left(\mathrm{C}_{\text {metal }} * \mathrm{D}_{\text {food intake }}\right)$

where $C_{\text {metal }}$ and $D_{\text {food intake }}$ represent the heavy metal concentrations in gluten-free food and daily intake of food, respectively. The average daily intake of gluten free food was considered $100 \mathrm{~g} /$ person/day.

Dietary intake levels for celiac people were estimated for essential nutrients (Tables 5, 6). (See Table 4.)

Consuming the considered daily amount of $100 \mathrm{~g}$ of gluten-free food, these supply from 2.6 to $4127 \%$ of chromium, $1.7-33 \%$ of manganese, $1.6-20 \%$ of copper, $1-125 \%$ of zinc, $11-105 \%$ of selenium, $58-829 \%$ of molybdenum and $1.4-13.0 \%$ of zinc of the Reference Adequate Intake (RDA) or for men adults (70 Kg).

The Dietary Reference Intake (RDI) for iron is significantly different for males and females, thus, considering the mean value concentrations of all the samples analyzed, while males may obtain as much as $39 \%$ of their RDI from gluten free foods the contribution to RDI for females is $17 \%$. For iron, the lowest RDI values were obtained for the samples no. 1 (pasta) and no. 11 (rice noodles).

Meanly, gluten-free foods are a low source of several elements (chromium, copper, selenium and zinc). Considering our data, the range of lead daily intake was $0.002-2.0 \mu \mathrm{gg}^{-1} \mathrm{~d}^{-1}$. In four samples, higher total intake compared to the established values was observed.

Table 3

Contamination categories based on EF values.

\begin{tabular}{ll}
\hline EF $>2$ & Deficiency to minimal enrichment \\
EF $2-5$ & Moderate enrichment \\
EF $5-20$ & Significant enrichment \\
EF $20-40$ & Very high enrichment \\
EF $>40$ & Extremely high enrichment \\
\hline
\end{tabular}

The highest values were found consuming $100 \mathrm{~g}$ of biscuits (sample no. 22), local bread (sample no. 20), corn flakes (sample no. 16) and pasta (sample no. 1). The lead intake by the mean adult population in the Member States is estimated to be $0.042 \mathrm{mg} \mathrm{day}^{-1}$, while, in Italy, the mean daily intake is $0.030 \mathrm{mg} /$ day [34]. The most important source is fruit, which contributes $0.017 \mathrm{mg} \mathrm{day}^{-1}$. Cereals and bakery ware are the 2 nd largest source with $0.004 \mathrm{mg} \mathrm{day}^{-1}$ [34].

A provisional tolerable weekly intake (PTWI) of $5 \mu \mathrm{gg}^{-1}$ week bodyweight corresponding to $0.7 \mu \mathrm{g} \mathrm{kg}^{-1}$ day $^{-1}$ has been decided for total mercury [34]. Considering our data, the range of mercury daily intake (0.0002-0.24 $\mu \mathrm{g} \mathrm{kg}^{-1} \mathrm{~d}^{-1}$ ) was lower than tolerable value.

\subsection{Health Risk Index (HRI)}

The concentrations of hazardous elements were used in the intake calculation, since this methodology is internationally accepted to provide satisfactory estimates of long-term exposure, suitable for comparison with the respective toxicological values.

Concerning the health risks derived from the intakes of the hazardous elements, the results derived from this research were compared with the available toxicological values [35-38].

The European Food Safety Authority (EFSA) [36-38], on account of data related to lung cancer in humans, established that a range of 0.3-8 $\mu \mathrm{g} \mathrm{kg}^{-1} \mathrm{~d}^{-1}$ should be used as a reference point for valuating risk associated with arsenic [37]. Successively, according to new approaches of EFSA, based on increased incidence of lung cancer in human, the reference value would be $3 \mu \mathrm{gg}^{-1} \mathrm{~d}^{-1}$.

Concerning cadmium, the EFSA established a tolerable weekly intake of $2.5 \mu \mathrm{g} \mathrm{kg}^{-1}$, corresponding to about $0.36 \mu \mathrm{g} \mathrm{kg}{ }^{-1} \mathrm{~d}^{-1}$. Also, JECFA [39, 40 ] set a provisional tolerable monthly intake of $25 \mathrm{\mu g} \mathrm{kg}^{-1}$ corresponding to $0.83 \mu \mathrm{g} \mathrm{kg}^{-1} \mathrm{~d}^{-1}$. In our case (Table 7), for adults the estimated intake of cadmium through the studied food was lower than the reported values. 
Table 4

Enrichment factors (EFs) in gluten-free food samples analyzed.

\begin{tabular}{|c|c|c|c|c|c|c|c|c|c|c|c|c|c|c|c|c|c|c|}
\hline Sample & V & $\mathrm{Cr}$ & Mn & Co & $\mathrm{Ni}$ & $\mathrm{Cu}$ & $\mathrm{Zn}$ & As & Se & $\mathrm{Sr}$ & Mo & $\mathrm{Cd}$ & Sn & $\mathrm{Sb}$ & $\mathrm{Ba}$ & $\mathrm{Hg}$ & $\mathrm{Pb}$ & $\mathrm{Fe}$ \\
\hline $1 \mathrm{~Pa}$ & -07 & $E-05$ & $E-04$ & -06 & $E-04$ & $E-03$ & $\mathrm{E}-02$ & $E-04$ & $1.9 E-01$ & $4.1 \mathrm{E}-05$ & $2 E-02$ & $1.2 \mathrm{E}-02$ & $3.4 \mathrm{E}-03$ & $8.8 \mathrm{E}-03$ & $1.0 \mathrm{E}-04$ & $1.3 \mathrm{E}$ & $2.5 \mathrm{E}-02$ & $1.8 \mathrm{E}-05$ \\
\hline & & & $E-03$ & & & & -02 & -03 & & -04 & $E-01$ & -02 & -03 & -02 & -04 & & -04 & \\
\hline 3 Flour & -05 & & $E-03$ & -05 & -04 & & & & & & & $E-02$ & & & & & -05 & \\
\hline 4 Biscuits & $E-05$ & $E-04$ & $E-03$ & $E-04$ & $E-03$ & $E-02$ & $E-02$ & $E-03$ & $E-01$ & $E-04$ & $E-02$ & $6.4 \mathrm{E}-02$ & $3 E-03$ & $E-02$ & $3 E-04$ & $7 \mathrm{E}-03$ & $9 \mathrm{E}-04$ & $5 E-05$ \\
\hline & & $E-05$ & & & & & $\mathrm{E}-02$ & & & & $7 E-02$ & & & & & & & $1.0 \mathrm{E}-04$ \\
\hline $6 \mathrm{~Pa}$ & -05 & $E-04$ & 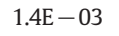 & 3 & 3 & 3 & 22 & & & & & & & & & & -04 & -04 \\
\hline & & & & & & & & & & & & & & & & & & \\
\hline 8 Fin & & & & & & & & & & & & & & & & & & \\
\hline & & & & & & & & & & & & & & & & & & \\
\hline & & & & & & & & & & & & & & & & & & \\
\hline & & & & & & & & & & & & & & & 03 & & & 05 \\
\hline & & & & & & & & & & & & & & & -04 & & & \\
\hline & & & & & & & & & & & & & & & & & & \\
\hline $14 \mathrm{Fl}$ & 05 & 04 & $E-04$ & & & & & 03 & & & & & & & 03 & & & \\
\hline & & & & & & & & & & & & & & & & & & \\
\hline & & & & & & & & & & & & & & & 03 & & 02 & 04 \\
\hline & & & & & & & & & & & & & & & & & & \\
\hline & & & & & & & & & & & & & & & & & & -03 \\
\hline 19 Lo & $5.4 \mathrm{E}-04$ & $7.1 \mathrm{E}-02$ & $3.0 \mathrm{E}-03$ & $5.9 \mathrm{E}-03$ & $1.0 \mathrm{E}-01$ & -02 & -02 & $E-03$ & -01 & -02 & $2.0 \mathrm{E}-01$ & -01 & $1.5 \mathrm{E}-03$ & $\mathrm{E}-02$ & $7.2 \mathrm{E}-03$ & $4.6 \mathrm{E}-01$ & $2.0 \mathrm{E}-02$ & $1.1 \mathrm{E}-03$ \\
\hline & $27 \mathrm{~F}-04$ & & $6 F-03$ & $56 \mathrm{~F}-03$ & $10 \mathrm{~F}-01$ & $F-02$ & $F-01$ & & & & & & & & & & & \\
\hline 21 Cor & $2.3 \mathrm{E}-04$ & $E-02$ & $E-03$ & $5.1 \mathrm{E}-03$ & $1.0 \mathrm{E}-01$ & $1.6 \mathrm{E}-02$ & $4.6 \mathrm{E}-02$ & $4.8 \mathrm{E}-03$ & 1. & -03 & $2.4 \mathrm{E}-01$ & $1.5 \mathrm{E}-01$ & $1.7 \mathrm{E}-03$ & $2.4 \mathrm{E}-02$ & $2.3 \mathrm{E}-03$ & $1.7 \mathrm{E}-01$ & $1.5 \mathrm{E}-02$ & $9.7 \mathrm{E}-04$ \\
\hline & & & $36 \mathrm{~F}-03$ & & & & & & & & & & & & & & & \\
\hline 23 Biscl & $4.2 \mathrm{E}-04$ & $1.2 \mathrm{E}-01$ & $4.5 \mathrm{E}-03$ & $7.0 \mathrm{E}-03$ & $1.4 \mathrm{E}-01$ & 2. & $9.8 \mathrm{E}-02$ & $1.8 \mathrm{E}-02$ & +00 & -03 & $2 . c$ & 02 & -03 & 01 & -03 & $2.8 \mathrm{E}-01$ & $5.7 \mathrm{E}-03$ & $1.3 \mathrm{E}-03$ \\
\hline & & & & & & & & & & & & & & & & & & \\
\hline & & & & & & & & & & & & & & & & & & $1.7 E-04$ \\
\hline & & & & & & & & -02 & & & & & & & & & & \\
\hline & $3.8 \mathrm{E}-04$ & $4.4 \mathrm{E}-04$ & $2.0 \mathrm{E}-03$ & $5.3 \mathrm{E}-04$ & $1.8 \mathrm{E}-03$ & $4 \mathrm{E}-02$ & $3 E-02$ & $1.1 \mathrm{E}-02$ & $2.7 \mathrm{E}-01$ & $4.0 \mathrm{E}-03$ & $2.3 \mathrm{E}-01$ & $3.1 \mathrm{E}-02$ & $1.3 \mathrm{E}-03$ & $1.6 \mathrm{E}-02$ & $1.5 \mathrm{E}-03$ & $7.3 \mathrm{E}-02$ & $4.0 \mathrm{E}-03$ & $3.4 \mathrm{E}-04$ \\
\hline
\end{tabular}


Table 5

Percentage of contribution to Daily Reference Intake for metals in gluten - free food samples.

\begin{tabular}{|c|c|c|c|c|c|c|c|c|c|c|c|c|c|c|}
\hline Sample & V & $\mathrm{Cr}$ & Mn & $\mathrm{Ni}$ & $\mathrm{Cu}$ & $\mathrm{Zn}$ & As & Se & $\mathrm{Sr}$ & Mo & $\mathrm{Cd}$ & $\mathrm{Hg}$ & $\mathrm{Pb}$ & $\mathrm{Fe}$ \\
\hline 1 Pasta & 0.06 & 0.0026 & 2.0 & 0.22 & 2.9 & 1.1 & 0.19 & 1.7 & 0.026 & 17 & 0.54 & 0.14 & 12 & 1.4 \\
\hline 2 Noodles & 0.38 & 0.0076 & 7.1 & 0.70 & 6.4 & 4.0 & 6.6 & 4.7 & 0.59 & 30 & 1.2 & 0.10 & 0.23 & 5.80 \\
\hline 3 Flour & 2.2 & 0.0044 & 5.4 & 0.32 & 1.6 & 1.0 & 4.1 & 1.4 & 0.63 & 9.2 & 0.86 & 0.07 & 0.05 & 3.20 \\
\hline 4 Biscuits & 2.2 & 0.0043 & 17 & 3.1 & 10 & 4.2 & 3.2 & 3.0 & 0.31 & 24 & 2.9 & 0.05 & 0.19 & 5.80 \\
\hline 5 Pasta fusilli & 1.9 & 0.0033 & 5.9 & 3.5 & 5.4 & 3.5 & 0.2 & 3.1 & 0.18 & 7.3 & 0.54 & 0.02 & 0.12 & 7.76 \\
\hline 6 Pasta linguine & 3.7 & 0.0222 & 6.3 & 7.6 & 5.5 & 3.5 & 0.19 & 2.5 & 0.18 & 7.9 & 0.50 & 0.02 & 0.13 & 12 \\
\hline 7 Egg noodles & 1.1 & 0.0089 & 8.4 & 0.86 & 5.1 & 3.7 & 5.4 & 10 & 1.3 & 21 & 2.4 & 0.01 & 0.05 & 6.8 \\
\hline 8 Finger biscuits & 3.2 & 0.045 & 3.5 & 1.4 & 4.9 & 5.1 & 8.7 & 12 & 1.9 & 45 & 0.68 & 0.33 & 1.3 & 11 \\
\hline 9 Buckwheat biscuits & 4.63 & 0.011 & 22 & 4.7 & 18 & 5.9 & 9.5 & 2.8 & 0.38 & 58 & 5.0 & 0.42 & 1.1 & 10 \\
\hline 10 Croutons & 14 & 0.060 & 33 & 7.2 & 6.9 & 3.3 & 11 & 6.7 & 7.8 & 82 & 2.3 & 0.43 & 1.3 & 17 \\
\hline 11 Rice noodles & 1.6 & 0.038 & 22 & 2.0 & 19 & 9.8 & 44 & 4.9 & 0.73 & 104 & 7.4 & 0.68 & 0.94 & 4.5 \\
\hline 12 Couscous & 1.4 & 0.012 & 4.6 & 4.4 & 5.3 & 2.9 & 4.1 & 4.1 & 0.27 & 45 & 1.3 & 0.21 & 0.86 & 5.3 \\
\hline 13 Corn couscous & 2.7 & 0.018 & 3.5 & 1.6 & 4.1 & 2.6 & 3.9 & 1.6 & 0.26 & 25 & 0.79 & 0.14 & 0.92 & 6.3 \\
\hline 14 Flour for cakes & 4.2 & 0.022 & 1.7 & 0.59 & 3.6 & 6.1 & 5.6 & 13 & 2.4 & 40 & 0.75 & 0.14 & 0.94 & 12 \\
\hline 15 Lasagna & 36 & 4.1 & 11 & 212 & 17 & 6.5 & 8.4 & 11 & 3.1 & 90 & 5.9 & 4.5 & 7.9 & 124 \\
\hline 16 Corn flakes & 14 & 2.4 & 9.2 & 147 & 12 & 3.0 & 4.3 & 11 & 1.2 & 67 & 12 & 2.5 & 12.8 & 69 \\
\hline 17 Dietetic biscuits & 24 & 2.6 & 6.7 & 143 & 13 & 3.3 & 7.1 & 2.8 & 2.4 & 54 & 3.6 & 9.0 & 7.0 & 78 \\
\hline 18 breadsticks & 18 & 2.5 & 19 & 150 & 12 & 4.6 & 18 & 4.8 & 1.2 & 63 & 5.8 & 11 & 3.8 & 78 \\
\hline 19 Local bread B. & 37 & 2.5 & 14 & 148 & 19 & 5.3 & 6.9 & 3.4 & 8.5 & 53 & 6.6 & 5.1 & 9.7 & 83 \\
\hline 20 Local bread P. & 18 & 2.5 & 21 & 146 & 20 & 7.6 & 28 & 2.4 & 3.7 & 73 & 9.1 & 18 & 145 & 88 \\
\hline 21 Corn flakes & 16 & 2.3 & 9.3 & 143 & 12 & 3.2 & 4.3 & 12 & 0.93 & 64 & 6.8 & 1.9 & 7.4 & 75 \\
\hline 22 Shortbread & 17 & 2.8 & 16 & 177 & 16 & 125 & 22 & 5.9 & 0.85 & 81 & 34 & 2.0 & 40.3 & 101 \\
\hline 23 Biscuits & 29 & 4.0 & 21 & 200 & 18 & 6.7 & 16 & 9.2 & 1.6 & 77 & 4.5 & 3.1 & 2.7 & 104 \\
\hline 24 Butter cookies & 27 & 4.0 & 20 & 197 & 13 & 5.4 & 21 & 1.6 & 0.54 & 92 & 6.9 & 3.0 & 2.3 & 94 \\
\hline 25 Croutons & 2.6 & 0.009 & 19 & 1.5 & 20 & 6.1 & 31 & 3.8 & 2.5 & 81 & 3.9 & 2.3 & 0.9 & 13 \\
\hline 26 Egg biscuits & 7.1 & 0.010 & 26 & 3.0 & 14 & 5.7 & 28 & 2.9 & 2.6 & 71 & 5.9 & 1.3 & 1.0 & 5.7 \\
\hline 27 Industrial bread & 26 & 0.015 & 9.4 & 2.5 & 10 & 3.3 & 9.8 & 2.5 & 2.6 & 61 & 1.4 & 0.82 & 1.9 & 26 \\
\hline Mean value & 12 & 1.1 & 13 & 63 & 11 & 9.0 & 12 & 5.4 & 1.8 & 53 & 4.9 & 2.50 & 4.9 & 39 \\
\hline
\end{tabular}

Concerning lead, the previously established PTWI of $3.6 \mu \mathrm{gg}^{-1} \mathrm{~d}^{-1}$ was set by JECFA in 1986 [41]. Recently, EFSA [38] and JECFA [40] both acknowledged that this PTWI was not sufficiently protective and consequently identified three reference dietary intake values, two for adults and one for children/pregnant women and women of childbearing age. They were respectively $0.63 \mu \mathrm{gg}^{-1} \mathrm{~d}^{-1}, 1.5 \mu \mathrm{g} \mathrm{kg} \mathrm{g}^{-1}$ and $0.5 \mu \mathrm{g} \mathrm{kg}{ }^{-1} \mathrm{~d}^{-1}[38]$.

Table 7 shows HRI of toxic element intakes for the celiac adult people ( $70 \mathrm{~kg}$ ) through consumption of $100 \mathrm{~g} \mathrm{day}^{-1}$ of the gluten free food from the Italian market. The HRI was calculated as the ratio of estimated exposure of gluten-free foods and oral reference dose $[35,42,43]$. Tolerable upper intake levels, used in this paper, were shown in Table 7 (first line).

Estimated exposure is obtained by dividing daily intake of heavy metals by their safe limits. An index more than 1 is considered as not safe for human health. Considering our data, health risk index was lower than 1 for all the samples except nickel in a sample: lasagna (no. 15).

\section{Conclusion}

This paper is the first analytical approach to the study of twenty heavy metals in the gluten-free foods for celiac people. In this study a total of 27 different foods produced in Italy were investigated. Only the ICP-MS technique was used to investigate the elemental composition. One of the advantages about the use of ICP-MS for this characterization is the high sensitivity that improved the limits of quantification levels for some elements like chrome, arsenic, and molybdenum that are presents at low levels in some samples. The data indicate a considerable variability between samples with respect to metal concentrations, which could be due to the proportion of different ingredients used in the food compositions and to different levels of contaminants in the production laboratories.

Gluten-free foods analyzed contain levels of trace elements under the limits tolerated by the law and the contribution of the foods evaluated to the daily intake of all the elements analyzed remains under the recommended levels by international organisms.

Considering the average concentrations of some trace elements found in the present study, it can be concluded that they are inadequate if compared with the recommended daily intake by international organisms, providing from 1.1 to $53 \%$ of the RDI for the essential metals. Therefore, the index of the nutritional quality for gluten-free food products with respect to all the metals seems to be relatively poor. These conclusions are in good agreement to some authors affirming that commercial gluten-free cereal foods,

Table 6

Mean percentage of contribution to Daily Reference Intake for metals in gluten - free food samples.

\begin{tabular}{|c|c|c|c|c|c|c|}
\hline Element & Mean (mg/Kg) & Daily intake (mg/Kg) & RDI men (mg/d) & RDI females (mg/d) & \% Men RDI & \% Females RDI \\
\hline $\mathrm{Cr}$ & 3.9 & 0.39 & 35 & 25 & 1.1 & 1.6 \\
\hline $\mathrm{Cu}$ & 0.990 & 0.10 & 0.9 & 0.9 & 11 & 11 \\
\hline $\mathrm{Fe}$ & 31. & 3.1 & 8.0 & 18.0 & 39 & 17 \\
\hline $\mathrm{Mn}$ & 2.9 & 0.29 & 2.3 & 1.8 & 13 & 16 \\
\hline Mo & 0.24 & 0.02 & 0.045 & 0.045 & 53 & 53 \\
\hline Se & 0.030 & 0.003 & 0.055 & 0.055 & 5.5 & 5.5 \\
\hline $\mathrm{Zn}$ & 9.9 & 1.0 & 11.0 & 8.0 & 9.0 & 12.4 \\
\hline Mean & & & & & 19 & 17 \\
\hline
\end{tabular}


Table 7

Health Risk Index (HRI) for metals in gluten - free food samples.

\begin{tabular}{|c|c|c|c|c|c|c|c|c|c|c|c|c|c|}
\hline $\begin{array}{l}\text { Sample } \\
\text { Tolerable upper intake levels ( } \mu \mathrm{g} / \mathrm{kg} \text { dav) }\end{array}$ & $\begin{array}{l}\mathrm{Cr} \\
1500\end{array}$ & $\begin{array}{l}\text { Mn } \\
140\end{array}$ & $\begin{array}{l}\mathrm{Ni} \\
20\end{array}$ & $\begin{array}{l}\mathrm{Cu} \\
37\end{array}$ & $\begin{array}{l}\mathrm{Zn} \\
300\end{array}$ & $\begin{array}{l}\text { As } \\
3.0\end{array}$ & $\begin{array}{l}\text { Se } \\
5.7\end{array}$ & $\begin{array}{l}\text { Mo } \\
29\end{array}$ & $\begin{array}{l}\mathrm{Cd} \\
0.36\end{array}$ & $\begin{array}{l}\mathrm{Sb} \\
0.4\end{array}$ & $\begin{array}{l}\mathrm{Ba} \\
200\end{array}$ & $\begin{array}{l}\mathrm{Hg} \\
0.57\end{array}$ & $\begin{array}{l}\mathrm{Pb} \\
0.36\end{array}$ \\
\hline 1 Pasta & $8.7 \mathrm{E}-06$ & 0.005 & 0.001 & 0.0099 & 0.006 & 0.0002 & 0.0024 & 0.0037 & 0.0074 & 0.006 & 0.00029 & 0.0025 & 1.3 \\
\hline 2 Noodles & $2.5 \mathrm{E}-05$ & 0.017 & 0.003 & 0.022 & 0.021 & 0.0063 & 0.0064 & 0.0067 & 0.017 & 0.016 & 0.0027 & 0.0019 & 0.02 \\
\hline 3 Flour & $1.5 \mathrm{E}-05$ & 0.013 & 0.002 & 0.0054 & 0.005 & 0.0039 & 0.0019 & 0.0021 & 0.012 & 0.010 & 0.0029 & 0.0013 & 0.00 \\
\hline 4 Biscuits & $1.4 \mathrm{E}-05$ & 0.040 & 0.015 & 0.036 & 0.022 & 0.0030 & 0.0041 & 0.0054 & 0.041 & 0.016 & 0.0012 & 0.00094 & 0.02 \\
\hline 5 Pasta fusilli & $1.1 \mathrm{E}-05$ & 0.014 & 0.018 & 0.019 & 0.018 & 0.00018 & 0.0043 & 0.0016 & 0.0074 & 0.009 & 0.00066 & 0.00031 & 0.01 \\
\hline 6 Pasta linguine & $7.4 \mathrm{E}-05$ & 0.015 & 0.038 & 0.0191 & 0.018 & 0.00018 & 0.0034 & 0.0018 & 0.0069 & 0.095 & 0.00054 & 0.00031 & 0.01 \\
\hline 7 Egg noodles & $3.0 \mathrm{E}-05$ & 0.020 & 0.004 & 0.018 & 0.019 & 0.0051 & 0.014 & 0.0047 & 0.033 & 0.009 & 0.0019 & 0.00025 & 0.01 \\
\hline 8 Finger biscuits & $1.5 \mathrm{E}-04$ & 0.008 & 0.007 & 0.017 & 0.027 & 0.0083 & 0.016 & 0.010 & 0.0094 & 0.034 & 0.0022 & 0.0060 & 0.14 \\
\hline 9 Buckwheat biscuits & $3.8 \mathrm{E}-05$ & 0.051 & 0.024 & 0.061 & 0.031 & 0.0090 & 0.0039 & 0.013 & 0.069 & 0.033 & 0.0032 & 0.0075 & 0.11 \\
\hline 10 Croutons & $2.0 \mathrm{E}-04$ & 0.077 & 0.036 & 0.024 & 0.017 & 0.0106 & 0.0092 & 0.018 & 0.031 & 0.068 & 0.0055 & 0.0078 & 0.14 \\
\hline 11 Rice noodles & $1.3 \mathrm{E}-04$ & 0.052 & 0.010 & 0.066 & 0.051 & 0.0421 & 0.0067 & 0.023 & 0.102 & 0.029 & 0.0071 & 0.012 & 0.10 \\
\hline 12 Couscous & $3.8 \mathrm{E}-05$ & 0.011 & 0.022 & 0.019 & 0.015 & 0.0039 & 0.0057 & 0.010 & 0.017 & 0.019 & 0.0010 & 0.0038 & 0.09 \\
\hline 13 Corn couscous & $6.0 \mathrm{E}-05$ & 0.008 & 0.008 & 0.014 & 0.014 & 0.0037 & 0.0022 & 0.006 & 0.011 & 0.036 & 0.0010 & 0.0025 & 0.10 \\
\hline 14 Flour for cakes & $7.4 \mathrm{E}-05$ & 0.004 & 0.003 & 0.013 & 0.032 & 0.0053 & 0.018 & 0.009 & 0.010 & 0.084 & 0.0038 & 0.0025 & 0.10 \\
\hline 15 Lasagna & $1.4 \mathrm{E}-02$ & 0.026 & 1.2 & 0.059 & 0.034 & 0.0080 & 0.016 & 0.020 & 0.081 & 0.094 & 0.0063 & 0.081 & 0.85 \\
\hline 16 Corn flakes & $8.0 \mathrm{E}-03$ & 0.022 & 0.73 & 0.0423 & 0.016 & 0.0041 & 0.015 & 0.015 & 0.16 & 0.024 & 0.0065 & 0.046 & 1.4 \\
\hline 17 Dietetic biscuits & $8.7 \mathrm{E}-03$ & 0.016 & 0.71 & 0.045 & 0.018 & 0.0067 & 0.0039 & 0.012 & 0.050 & 0.050 & 0.0044 & 0.16 & 0.75 \\
\hline 18 Breadsticks & $8.3 \mathrm{E}-03$ & 0.045 & 0.75 & 0.043 & 0.024 & 0.0170 & 0.0066 & 0.014 & 0.081 & 0.045 & 0.0032 & 0.20 & 0.41 \\
\hline 19 Local bread B. & $8.3 \mathrm{E}-03$ & 0.032 & 0.74 & 0.0661 & 0.028 & 0.0065 & 0.0047 & 0.012 & 0.091 & 0.060 & 0.0201 & 0.09 & 1.04 \\
\hline 20 Local bread P. & $8.3 \mathrm{E}-03$ & 0.049 & 0.73 & 0.071 & 0.040 & 0.0268 & 0.0033 & 0.016 & 0.13 & 0.057 & 0.0045 & 0.32 & 1.55 \\
\hline 21 Corn flakes & $7.7 \mathrm{E}-03$ & 0.022 & 0.72 & 0.041 & 0.017 & 0.0041 & 0.016 & 0.014 & 0.094 & 0.017 & 0.0063 & 0.034 & 0.79 \\
\hline 22 Shortbread & $9.2 \mathrm{E}-03$ & 0.039 & 0.89 & 0.0540 & 0.65 & 0.0209 & 0.0082 & 0.018 & 0.473 & 0.034 & 0.0045 & 0.037 & 4.31 \\
\hline 23 Biscuits & $1.3 \mathrm{E}-02$ & 0.048 & 1.0 & 0.0613 & 0.035 & 0.0154 & 0.013 & 0.017 & 0.062 & 0.10 & 0.0033 & 0.055 & 0.29 \\
\hline 24 Butter cookies & $1.3 \mathrm{E}-02$ & 0.047 & 0.98 & 0.0438 & 0.028 & 0.0203 & 0.0022 & 0.021 & 0.096 & 0.057 & 0.0042 & 0.053 & 0.25 \\
\hline 25 Croutons & $2.9 \mathrm{E}-05$ & 0.045 & 0.008 & 0.0703 & 0.032 & 0.0296 & 0.0052 & 0.018 & 0.054 & 0.004 & 0.0027 & 0.042 & 0.10 \\
\hline 26 Egg biscuits & $3.3 \mathrm{E}-05$ & 0.062 & 0.015 & 0.0500 & 0.030 & 0.0262 & 0.0040 & 0.016 & 0.082 & 0.004 & 0.0023 & 0.024 & 0.11 \\
\hline 27 Industrial bread & $5.1 \mathrm{E}-05$ & 0.022 & 0.012 & 0.0362 & 0.017 & 0.0093 & 0.0034 & 0.014 & 0.020 & 0.011 & 0.0043 & 0.015 & 0.21 \\
\hline Mean value & $3.7 \mathrm{E}-03$ & 0.030 & 0.316 & 0.038 & 0.047 & 0.011 & 0.0074 & 0.012 & 0.068 & 0.038 & 0.0039 & 0.045 & 0.53 \\
\hline
\end{tabular}

made of refined flours or starches, are of lower nutritional value compared to their wheat counterparts [44].

The metal pollution index and health risk index of heavy metals also suggest that $\mathrm{Cd}, \mathrm{Pb}$ and $\mathrm{Ni}$ contamination in most of the test gluten-free food had potential for human health risk due to consumption of food at contaminated industrial laboratory.

\section{References}

[1] P.D. Howdle, Celiac (Coeliac) Disease Encyclopedia of Food Sciences and Nutrition, 2nd ed., 2003. 987-994.

[2] M.M. Niewinski, Advances in celiac disease and gluten-free diet, J. Am. Diet. Assoc. 108 (2008) 661-672.

[3] J.A. Curiel, R. Coda, A. Limitone, K. Katina, M. Raulio, G. Giuliani, C.G. Rizzello, M. Gobbetti, Manufacture and characterization of pasta made with wheat flou rendered gluten-free using fungal proteases and selected sourdough lactic acid bacteria, J. Cereal Sci. 59 (2014) 79-87.

[4] T. Thompson, Thiamin, riboflavin, and niacin contents of the gluten free diet: is there cause for concern? J. Am. Diet. Assoc. 99 (1999) 858-862.

[5] T. Thompson, Folate, iron, and dietary fiber contents of the gluten free diet, J. Am. Diet. Assoc. 100 (2000) 1389-1396.

[6] T. Thompson, M. Dennis, L.A. Higgins, A.R. Lees, M.K. Sharrett, Gluten-free diet survey: are Americans with celiac disease consuming recommended amounts of fibre, iron, calcium and grain foods? J. Hum. Nutr. Dietetics 18 (2005) 163-169.

[7] EC, Commission Regulation (EC) No 1881/2006 of 19 December 2006 setting maximum levels for certain contaminants in foodstuffs, Off. J. Eur. Union L364 (2006) 0005-0024.

[8] B. Škrbic, J. Zivancev, N. Mrmoš, Concentrations of arsenic, cadmium and lead in selected foodstuffs from Serbian market basket: Estimated intake by the population from the Serbia, Food Chem. Toxicol. 58 (2013) 440-448.

[9] FAO/WHO, Food Balance Sheet, Faostat.fao.org/site/368/default.aspx\#ancor 2007.

[10] L. Culotta, A. Gianguzza, S. Orecchio, A. Tagarelli Sand, Clams of Ganzirri Marine Coastal Lagoon in Messina (Italy). Extraction and ICP-MS analysis, Fresenius Environ. Bull. 17 (2008) 131-141.

[11] S. Orecchio, Microanalytical characterization of decorations in handmade ancient floor tiles using inductively coupled plasma optical emission spectrometry (ICP-OES), Microchem. J. 108 (2013) 137-150.

[12] E. Beccaloni, F. Vanni, M. Beccaloni, M. Carere, Concentrations of arsenic, cadmium, lead and zinc in homegrown vegetables and fruits: estimated intake by population in an industrialized area of Sardinia, Italy, Microchem. J. 107 (2013) 190-195.

[13] M.A. Radwan, A.K. Salama, Market basket survey for some heavy metals in Egyptian fruit and vegetables, Food Chem. Toxicol. 44 (2006) 1273-1278.

[14] G. Ysart, P. Miller, H. Crews, P. Robb, M. Baxter, C. De L'Argy, S. Lofthouse, C. Sargent, N. Harrison, Dietary exposure estimates of 30 elements from the UK total diet study, Food Addit. Contam. 16 (1999) 391-403.
[15] S. Orecchio, V. Papuzza, Levels, fingerprint and daily intake of polycyclic aromatic hydrocarbons (PAHs) in bread baked using wood as fuel, J. Hazard Mater. 164 (2009) 876-883.

[16] C. Hwang, S. Jiang, Determination of arsenic compounds in water samples by liquid chromatography-inductively coupled plasma mass spectrometry with an in situ nebulizer hydride generator, Anal. Chim. Acta 289 (1994) 205-213.

[17] S. Orecchio, S.G. Polizzotto, Fractionation of mercury in sediments during draining of Augusta (Italy) coastal area by modified Tessier method, Microchem. J. 110 (2013) 452-457.

[18] C. Benincasa, J. Lewis, E. Perri, G. Sindona, A. Tagarelli, Determination of trace element in Italian virgin olive oils and their characterization according to geographical origin by statistical analysis, Anal. Chim. Acta. 585 (2007) 366-370.

[19] M.N. Matos-Reyes, M.L. Cervera, R.C. Campos, M. de la Guardia, Total content of As $\mathrm{Sb}, \mathrm{Se}, \mathrm{Te}$ and $\mathrm{Bi}$ in Spanish vegetables, cereals and pulses and estimation of the contribution of these foods to the Mediterranean daily intake of trace elements, Food Chem. 122 (2010) 188-194.

[20] S. Millour, L. Noel, R. Chekri, C. Vastel, A. Kadar, V. Sirot, J.C. Leblanc, T. Guerin, Strontium, silver, tin, iron, tellurium, gallium, germanium, barium and vanadium levels in foodstuffs from the second French total diet study, J. Food Compos. Anal. 25 (2012) 108-129.

[21] B. Demirozu, I. Saldamli, B. Gursel, A. Ucak, F. Cetinyokus, N. Yuzbasi, Determination of some metals which are important for food quality control in bread, J. Cereal Sci. 37 (2003) 171-177.

[22] IARC (International Agency for Research on Cancer), IARC monographs on the evaluation of carcinogenic risks to humans, Inorganic and Organic Lead Compounds, vol. 86, 2006, (Lyon, France).

[23] L. Noëla, R. Chekri, S. Millour, C. Vastel, A. Kadar, V. Sirot, J.C. Leblanc, T. Guérin, Li, Cr, $\mathrm{Mn}, \mathrm{Co}, \mathrm{Ni}, \mathrm{Cu}, \mathrm{Zn}$, Se and Mo levels in foodstuffs from the Second French TDS, Food Chem. 132 (2012) 1502-1513.

[24] L. Nasreddine, O. Nashalian, F. Naja, L. Itani, D. Parent-Massin, M. Nabhani-Zeidan, N. Hwalla, Dietary exposure to essential and toxic trace elements from a Total diet study in an adult Lebanese urban population, Food Chem. Toxicol. 48 (2010) 1262-1269.

[25] M. Azizur Rahman, M.M. Rahman, S.M. Reichman, R.P. Lim, R. Naidu, Heavy metals in Australian grown and imported rice and vegetables on sale in Australia: health hazard, Ecotoxicol. Environ. Saf. 100 (2014) 53-60.

[26] M. Sigrist, L. Brusa, D. Campagnoli, H. Beldoménico, Determination of selenium in selected food samples from Argentina and estimation of their contribution to the Se dietary intake, Food Chem. 134 (2012) (1932-1937).

[27] J. Murphy, K. Cashman, Selenium content of a range of Irish foods, Food Chem. 74 (2001) 493-498.

[28] M.P. Rayman, Food-chain selenium and human health: emphasis on intake, Br. J. Nutr. 100 (2008) 254-268

[29] S. McNaughton, G. Marks, Selenium content of Australian foods: a review of literature values, J. Food Compos. Anal. 15 (2002) 169-182.

[30] R. Pagliaro Avegliano, V.A. Maihara, F.F. da Silva, A Brazilian total diet study: evaluation of essential elements a Brazilian total diet study: evaluation of essential elements, J. Food Compos. Anal. 24 (2011) 1009-1016. 
[31] J. Usero, E. Gonzalez-Regalado, I. Gracia, Trace metals in the bivalve molluscs Ruditapes decussatus and Ruditapes philippinarum from the Atlantic Coast of Southern Spain, Environ. Int. 23 (1997) 291-298.

[32] K. Loska, D. Wiechuya, Application of principle component analysis for the estimation of source of heavy metal contamination in surface sediments from the Rybnik reservoir, Chemosphere 51 (2003) 723-733.

[33] R.F. Nolting, A. Ramkema, J.M. Everaarts, The geochemistry of $\mathrm{Cu}, \mathrm{Cd}, \mathrm{Zn}$, Ni and $\mathrm{Pb}$ in sediment cores from the continental slope of the Banc d'Arguin (Mauritania), Cont. Shelf Res. 19 (1999) 665-691.

[34] SCOOP, (Scientific Cooperation on Questions relating to Food), Task 3.2.11, Assessment of Dietary Intake of Arsenic, Cadmium, Lead and Mercury by the Population of EU Members' States, 2004.

[35] K. Khan, Y. Lu, H. Khan, M. Ishtiaq, S. Khan, M. Waqas, L. Wei, T. Wang, Heavy metals in agricultural soils and crops and their health risks in Swat District, northern Pakistan, Food Chem. Toxicol. 58 (2013) 449-458.

[36] EFSA (European Food Safety Authority), EFSA panel on contaminants in the food chain (CONTAM). Scientific opinion of the panel on contaminants in the food chain. Cadmium in food. Adopted on 30 January 2009, EFSA J. 980 (2009) 1-139.

[37] EFSA (European Food Safety Authority), EFSA panel on contaminants in the food chain (CONTAM). Scientific opinion on arsenic in food. Adopted on 12 October 2009, EFSA J. 7 (2009) 1351199.
[38] EFSA (European Food Safety Authority), EFSA panel on contaminants in the food chain (CONTAM). Scientific opinion on lead in food. Adopted on 18 March 2010, EFSA J. 8 (4) (2010) 1570 (1-147).

[39] JECFA (Joint FAO/WHO Expert Committee on Food Additives), Evaluation of certain food additives and contaminants, 72nd Report of the Joint FAO/WHO Expert Committee on Food Additive, WHO Technical Report Series 959, 2011 1-106.

[40] JECFA (Joint FAO/WHO Expert Committee on Food Additives), Evaluation of certain food additives and contaminants, 73rd Report of the Joint FAO/WHO Expert Committee on Food Additive, WHO Technical Report Series 960, 2011.

[41] JECFA (Joint FAO/WHO Expert Committee on Food Additives), Evaluation of certain food additives and contaminants, 79th Report of the Joint FAO/WHO Expert Committee on Food Additives, WHO Technical Report Series 733, 1986.

[42] A. Singh, R.K. Sharma, M. Agrawal, F.M. Marshall, Health risk assessment of heavy metals via dietary intake of foodstuffs from the wastewater irrigated site of a dry tropical area of India, Food Chem. Toxicol. 48 (2010) 611-619.

[43] Yu-Jing Cui, Yong-Guan Zhu, Ri-Hong Zhai, Deng-Yun Chen, Yi-Zhong Huang, Yi Qiu, Jian-Zhong Liang, Transfer of metals from soil to vegetables in an area near a smelter in Nanning, China Environ. Int. 30 (2004) 785-791.

[44] K. Tsatsaragkou, G. Gounaropoulos, I. Mandala, Development of gluten free bread containing carob flour and resistant starch, LWT Food Sci. Technol. 58 (2014) 124-129. 